\title{
Arcyriaflavin E, a new cytotoxic indolocarbazole alkaloid isolated by combined-culture of mycolic acid-containing bacteria and Streptomyces cinnamoneus NBRC 13823
}

\author{
Shotaro Hoshino ${ }^{1}$, Lihan Zhang $^{1}$, Takayoshi Awakawa ${ }^{1}$, Toshiyuki Wakimoto ${ }^{1}$, Hiroyasu Onaka ${ }^{2}$ \\ and Ikuro Abe ${ }^{1}$
}

The Journal of Antibiotics (2015) 68, 342-344; doi:10.1038/ja.2014.147; published online 22 October 2014

\begin{abstract}
Among all actinomycetes, Streptomyces species are prolific sources of secondary metabolites, leading to the isolation of thousands of antibiotics and other bioactive compounds. ${ }^{1}$ Genomic analyses of several Streptomyces strains revealed that each contains around 30 biosynthesis gene clusters for secondary metabolite production. ${ }^{2-4}$ However, many of these genes remain cryptic under standard laboratory conditions, and these 'silent genes' are expected to be untapped sources for novel bioactive compounds.

Recent research has illustrated that some mycolic acid-containing bacteria, such as Tsukamurella, Rhodococcus, Corynebacterium, Gordonia and Nocardia species, interact with a broad range of Streptomyces strains and induce the production of cryptic secondary metabolites by co-culture. ${ }^{5,6}$ This 'combined-culture' method promises to lead to the discovery novel cryptic bioactive compounds produced by Streptomyces.

In this report we describe the isolation of arcyriaflavin E (2), a new cytotoxic indolocarbazole alkaloid, along with two known related alkaloids, BE-13793C (1) and arcyriaflavin A (3), from Streptomyces cinnamoneus NBRC 13823 (provided by the National Institute of Technology and Evaluation Biological Resource Center (Japan)). The production of these indolocarbazole alkaloids was induced by culturing the strain together with Tsukamurella pulmonis, a mycolic acidcontaining bacterium. ${ }^{5,7}$
\end{abstract}

\section{HPLC-UV ANALYSIS OF THE METABOLIC PROFILE OF S. CINNAMONEUS NBRC 13823}

S. cinnamoneus NBRC 13823 and T. pulmonis were separately inoculated into a 500-ml baffled Erlenmeyer flask (S. cinnamoneus NBRC 13823) and a 500-ml Erlenmeyer flask (T. pulmonis), each containing $100 \mathrm{ml}$ of $\mathrm{V}-22$ medium, composed of $1.0 \%$ starch, $0.5 \%$ glucose, $0.5 \%$ Bacto Tryptone (Difco), $0.3 \% \mathrm{NZ}$ case (Wako), $0.2 \%$ Yeast Extract (Difco), $0.1 \% \mathrm{~K}_{2} \mathrm{HPO}_{4}, 0.05 \% \mathrm{MgSO}_{4} \cdot 7 \mathrm{H}_{2} \mathrm{O}$ and $0.3 \%$ $\mathrm{CaCO}_{3}(\mathrm{pH}=7.0)$. S. cinnamoneus $\mathrm{NBRC} 13823$ was cultured at $30{ }^{\circ} \mathrm{C}$ for 3 days on a rotary shaker at 220 r.p.m., and T. pulmonis was cultivated in the same manner for 2 days.

A 3-ml portion of the S. cinnamoneus NBRC 13823 culture and $1 \mathrm{ml}$ of the T. pulmonis culture were simultaneously added to a $500-\mathrm{ml}$ baffled Erlenmeyer flask containing $100 \mathrm{ml}$ of A-3 M medium, consisting of $2.0 \%$ starch, $2.0 \%$ glycerol, $0.5 \%$ glucose, $1.5 \%$ Pharma media (Archer Daniels Midland Co.), 1.0\% HP-20 (Nihon Rensui) and $0.3 \%$ yeast extract $(\mathrm{pH}=7.0)$. In addition, $3 \mathrm{ml}$ of the $S$. cinnamoneus NBRC 13823 culture and $1 \mathrm{ml}$ of the T. pulmonis culture were individually inoculated in 500-ml baffled Erlenmeyer flasks containing $100 \mathrm{ml}$ of A-3M medium, as control cultures. They were all cultured at $30^{\circ} \mathrm{C}$ for 5.5 days on a rotary shaker at 160 r.p.m.

The cell pellets were collected after centrifugation of the fermentation broths, and were subjected to lyophilization. The freeze-dried cells were extracted with $50 \mathrm{ml}$ of a $\mathrm{CH}_{3} \mathrm{OH}-\mathrm{CHCl}_{3}$ mixture (50:50, v/v). The extracts were then subjected to an HPLC-UV analysis, performed on a $4.6 \times 250 \mathrm{~mm}$ Cosmosil $5 \mathrm{C}_{18}$-MS-II column (Nacalai Tesque, Kyoto, Japan), in a $\mathrm{CH}_{3} \mathrm{CN}$ (solvent $\mathrm{A}$ ) $/ \mathrm{H}_{2} \mathrm{O}$-containing $1 \%$ acetic acid (solvent B) gradient system (solvent A: 95-80\% (15 min)-0\% (45-50 min)), using a JASCO PU2080 pump to control the flow rate at $1.0 \mathrm{ml} \mathrm{min}-1$. All eluates were monitored by UV absorption at $315 \mathrm{~nm}$ (JASCO, Tokyo, Japan, MD-2010 Plus Multiwavelength Detector). As a result of the HPLC analysis, one significantly enhanced peak (compound $\mathbf{1}$ ) and two newly induced peaks (compounds 2 and 3) were observed when S. cinnamoneus NBRC 13823 was cultured with T. pulmonis (Figure 1).

\section{EXTRACTION AND ISOLATION OF COMPOUNDS 1-3}

To elucidate the structures of 1, 2 and 3, the cells from 1.51 of the combined culture were extracted with $800 \mathrm{ml}$ of a mixture of $\mathrm{CH}_{3} \mathrm{OH}$ $\mathrm{CHCl}_{3}(50: 50, \mathrm{v} / \mathrm{v})$, according to the same method described above. The extract was concentrated under reduced pressure to yield an oily liquid $(0.73 \mathrm{~g})$, and was separated by silica gel column 
chromatography using Silica Gel 60 N (63-210 $\mu \mathrm{m}$, Kanto Chemical Co., Tokyo, Japan) by stepwise elution with $\mathrm{CHCl}_{3}-\mathrm{CH}_{3} \mathrm{OH}$ mixtures $\left(\mathrm{CH}_{3} \mathrm{OH}: \mathrm{CHCl}_{3}=0: 100,1: 99,2: 98,5: 95,10: 90,20: 80,50: 50\right.$ and 100:0, v/v). The eluates containing compounds 1 (50:50 and $100: 0,150 \mathrm{mg}), 2$ (25:75, $150 \mathrm{mg})$ and 3 (2:98 and 5:95, $160 \mathrm{mg})$ were further purified by semi-preparative reverse-phase HPLC with a $10 \times 250 \mathrm{~mm}$ Cosmosil $5 \mathrm{C}_{18}$-MS-II column (Nacalai Tesque), using an aqueous $\mathrm{CH}_{3} \mathrm{CN}$ isocratic mode containing $0.1 \%$ trifluoroacetic acid (TFA) at a flow rate of $3.0 \mathrm{ml} \mathrm{min}^{-1}$, to yield $1(5.73 \mathrm{mg}, 35 \%$ aqueous $\left.\mathrm{CH}_{3} \mathrm{CN}\right), 2$ (3.23 mg, 53\% aqueous $\left.\mathrm{CH}_{3} \mathrm{CN}\right)$ and $3(1.21 \mathrm{mg}$, $56 \%$ aqueous $\mathrm{CH}_{3} \mathrm{CN}$ ).

\section{STRUCTURE ELUCIDATION OF COMPOUNDS 1-3}

The structures of $\mathbf{1}$ and $\mathbf{3}$ were determined to be BE-13793C and arcyriaflavin A, respectively (Figure 2a), by comparing their molecular formulae, UV spectra and a series of NMR spectra with literature data. 8,9
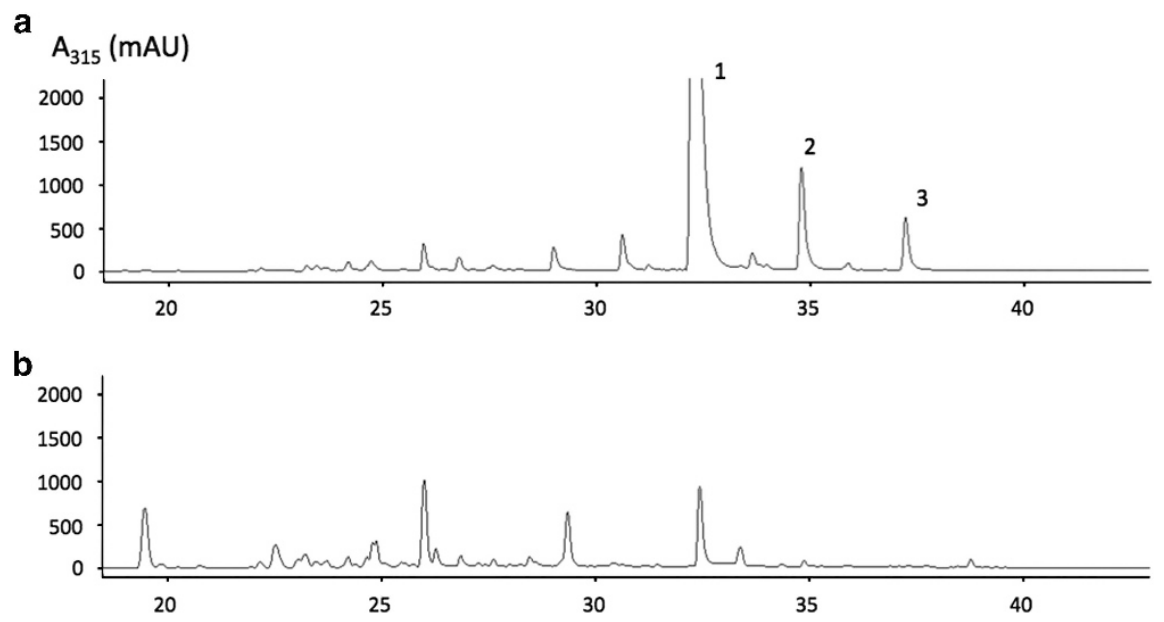

c

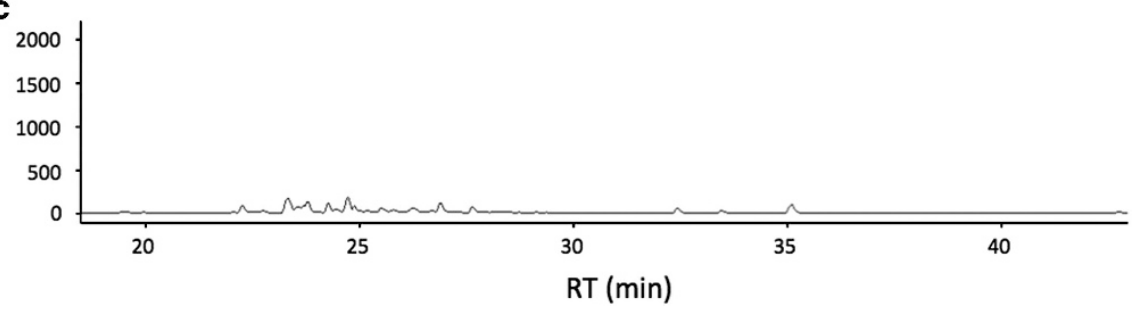

Figure 1 HPLC profiles of the extracts of Streptomyces cinnamoneus NBRC 13823 cultivated with T. pulmonis (a), NBRC 13823 pure culture (b) and T. pulmonis pure culture (c), monitored by UV absorption at $315 \mathrm{~nm}$.

a<smiles>O=C1NC(=O)c2c1c1c3cccc(O)c3[nH]c1c1[nH]c3c(O)cccc3c21</smiles><smiles></smiles><smiles>O=C1NC(=O)c2c1c1c3ccccc3[nH]c1c1[nH]c3ccccc3c21</smiles>

b

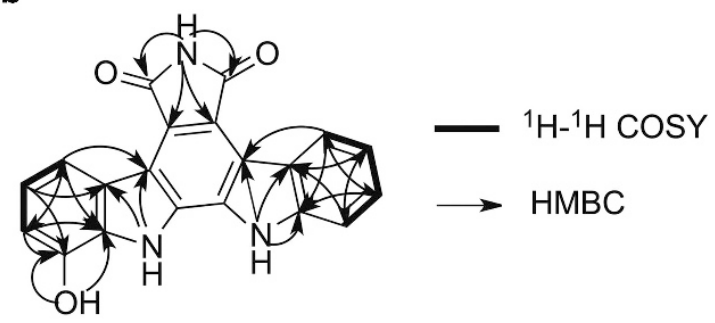

Figure 2 Chemical structures of $1-3$ (a) and ${ }^{1} \mathrm{H}-{ }^{1} \mathrm{H}$ COSY and $\mathrm{HMBC}$ correlations for 2 (b). 
Table 1 NMR spectroscopic data of arcyriaflavin E (2)

\begin{tabular}{|c|c|c|c|c|}
\hline \multirow{3}{*}{$\frac{\text { Position }}{1}$} & \multicolumn{4}{|c|}{2} \\
\hline & \multicolumn{2}{|c|}{$\delta_{C}$} & \multirow{2}{*}{$\frac{\delta_{H} \mathrm{~J}(H z)}{-}$} & \multirow{2}{*}{$\begin{array}{c}H M B C \\
-\end{array}$} \\
\hline & 143.4 & $\mathrm{qC}$ & & \\
\hline 2 & 111.1 & $\mathrm{CH}$ & $6.991 \mathrm{H}, \mathrm{d}, 8$ & $\mathrm{C} 1, \mathrm{C} 4, \mathrm{C} 13 \mathrm{a}$ \\
\hline 3 & 120.8 & $\mathrm{CH}$ & $7.141 \mathrm{H}, \mathrm{t}, 8$ & $\mathrm{C} 1, \mathrm{C} 4 \mathrm{a}$ \\
\hline 4 & 115.3 & $\mathrm{CH}$ & $8.431 \mathrm{H}, \mathrm{d}, 8$ & $c 2, c 4 b$ \\
\hline $4 a$ & 123.0 & $\mathrm{qC}$ & - & - \\
\hline $4 b$ & 115.9 & $\mathrm{qC}$ & - & - \\
\hline $4 c$ & $119.7^{a}$ & $\mathrm{qC}$ & - & - \\
\hline 5 & $171.3^{\mathrm{a}}$ & $\mathrm{qC}$ & - & - \\
\hline 6 & - & - & $10.951 \mathrm{H}, \mathrm{s}$ & $\mathrm{C} 4 \mathrm{c}, \mathrm{C} 5, \mathrm{C} 7, \mathrm{C7a}$ \\
\hline 7 & $171.4^{\mathrm{a}}$ & $\mathrm{qC}$ & - & - \\
\hline $7 a$ & $120.0^{\mathrm{a}}$ & $\mathrm{qC}$ & - & - \\
\hline $7 \mathrm{~b}$ & 115.1 & $\mathrm{qC}$ & - & - \\
\hline $7 c$ & 121.6 & $\mathrm{qC}$ & - & - \\
\hline 8 & 124.3 & $\mathrm{CH}$ & $8.981 \mathrm{H}, \mathrm{d}, 8$ & $\mathrm{C} 7 \mathrm{~b}, \mathrm{C} 10, \mathrm{C} 11 \mathrm{a}$ \\
\hline 9 & 120.2 & $\mathrm{CH}$ & $7.351 \mathrm{H}, \mathrm{t}, 8$ & C7c, C11 \\
\hline 10 & 126.7 & $\mathrm{CH}$ & $7.551 \mathrm{H}, \mathrm{t}, 8$ & $\mathrm{C} 8, \mathrm{C} 11 \mathrm{a}$ \\
\hline 11 & 112.0 & $\mathrm{CH}$ & $7.821 \mathrm{H}, \mathrm{d}, 8$ & $\mathrm{C7c}, \mathrm{C9}$ \\
\hline $11 a$ & 139.9 & $\mathrm{qC}$ & - & - \\
\hline 12 & - & - & $11.501 \mathrm{H}, \mathrm{s}$ & C7b, C7c, C11a, C12a/12b \\
\hline $12 a$ & $128.7^{\mathrm{a}}$ & $\mathrm{qC}$ & - & - \\
\hline $12 b$ & $129.2^{\mathrm{a}}$ & $\mathrm{qC}$ & - & - \\
\hline 13 & - & - & $11.741 \mathrm{H}, \mathrm{s}$ & $\mathrm{C} 4 \mathrm{a}, \mathrm{C} 4 \mathrm{~b}, \mathrm{C} 12 \mathrm{a} / 12 \mathrm{~b}$ \\
\hline $13 a$ & 130.3 & $\mathrm{qC}$ & - & - \\
\hline $1-\mathrm{OH}$ & - & - & $10.271 \mathrm{H}, \mathrm{s}$ & $\mathrm{C} 1, \mathrm{C} 13 \mathrm{a}$ \\
\hline
\end{tabular}

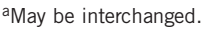

The new compound 2 was isolated as an orange powder, and its UV spectrum $\left(\lambda_{\max }:\left(\mathrm{CH}_{3} \mathrm{CN}\right): 239,287,311\right.$ and $\left.411 \mathrm{~nm}\right)$ is similar to those of $\mathbf{1}$ and 3. The molecular formula of $\mathbf{2}$ was determined to be $\mathrm{C}_{20} \mathrm{H}_{11} \mathrm{~N}_{3} \mathrm{O}_{3}$ (m/z found: $340.0743[\mathrm{M}-\mathrm{H}]^{-}$, calculated: 340.0722$)$ by an HR-Time-of-flight mass spectrometry (TOFMS) analysis (AccuTOF LC-plus JMS-T 100LP (JEOL)), and corresponds to the monodeoxygenated product of $\mathbf{1}$ or the mono-oxygenated product of 3 .

The structure of 2 was deduced by $1 \mathrm{D}$ and 2D NMR analyses. The ${ }^{1} \mathrm{H}$ NMR spectrum revealed the presence of 11 protons, consisting of 7 aromatic methine protons at $\delta 6.99(\mathrm{~d}, J=8 \mathrm{~Hz}), 7.14$ $(\mathrm{t}, J=8 \mathrm{~Hz}), 7.35(\mathrm{t}, J=8 \mathrm{~Hz}), 7.55(\mathrm{t}, J=8 \mathrm{~Hz}), 7.82(\mathrm{~d}, J=8 \mathrm{~Hz})$, $8.43(\mathrm{~d}, J=8 \mathrm{~Hz})$ and $8.98(\mathrm{~d}, J=8 \mathrm{~Hz})$, and 4 protons attached to the oxygen or nitrogen atoms at $\delta 10.27$ (s), 10.95 (s), 11.50 (s) and 11.74 (s). The ${ }^{13} \mathrm{C}$ NMR and HMQC spectra revealed that 2 contains 20 carbons, consisting of 2 carbonyl carbons at $\delta 171.26$ and 171.35, 11 aromatic quaternary carbons at $\delta 115.1,115.9,119.7,120.0,121.6$, $123.0,128.7,129.2,130.3,139.9$ and 143.4, and 7 aromatic methine carbons at $\delta 111.1,112.0,115.3,120.2,120.8,124.3$ and 126.7 (Table 1). These signals were assigned primarily on the basis of comparisons of the chemical shifts to those of $\mathbf{1}$ and $\mathbf{3}$. The presence of an isolated proton spin system of three aromatic protons at $\delta 6.99$, 7.14 and 8.43, along with two exchangeable protons at $\delta 10.27$ and
11.74, was reminiscent of the hydroxyindole found in $\mathbf{1}$. On the other hand, the other spin system of the four remaining aromatic protons at $\delta 7.35,7.55,7.82$ and 8.98 , with one exchangeable proton at $\delta 11.50$, was diagnostic for the indole moiety of 3 . As for the remaining exchangeable proton at $\delta 10.95$, the ${ }^{1} \mathrm{H}$ NMR spectra of 1 and 3 also showed corresponding signals (Supplementary Figures S1 and S8), assigned as maleimide protons. Finally, the HMBC correlations also support the presence of two indole rings (left hydroxyindole: correlations from $\mathrm{H} 2, \mathrm{H} 3, \mathrm{H} 4, \mathrm{H} 13$ and $\mathrm{C} 1-\mathrm{OH}$ protons; right indole: correlations from $\mathrm{H} 8, \mathrm{H} 9, \mathrm{H} 10, \mathrm{H} 11$ and $\mathrm{H} 12$, Figure 2b) and a maleimide moiety (correlation from H6, Figure $2 \mathrm{~b}$ ).

Thus, the structure of 2, named arcyriaflavin E, was elucidated as shown in Figure 2a as the C1-deoxy form of $\mathbf{1}$ (or the C1-hydroxy form of 3 ).

\section{CYTOTOXICITY ASSAY OF COMPOUNDS 1-3}

The cytotoxic activities of compounds $\mathbf{1 - 3}$ against P388 murine leukemia cells were tested, using the methyl-thiazole tetrazolium (MTT) assay. ${ }^{10}$ As a result, 1 and 2 showed cytotoxic activities with $\mathrm{IC}_{50} \mathrm{~s}$ of 33 and $39 \mu \mathrm{M}$, respectively, while 3 did not show any cytotoxicity up to a concentration of $100 \mu \mathrm{M}$.

In conclusion, we isolated a novel indolocarbazole, arcyriaflavin E, by the combined culture of T. pulmonis and S. cinnamoneus NBRC 13823. Our results illustrate that the combined culture with mycolic acid-containing bacteria is an efficient and convenient method for searching for novel natural compounds produced by Streptomyces strains.

\section{ACKNOWLEDGEMENTS}

We thank Dr Taro Ozaki and Dr Shumpei Asamizu (Graduate School of Agricultural and Life Sciences, The University of Tokyo) for their helpful advice.

1 Watve, M. G., Tickoo, R., Jog, M. M. \& Bhole, B. D. How many antibiotics are produced by the genus Streptomyces? Arch. Microbiol. 176, 386-390 (2001).

2 Bentley, S. D. et al. Complete genome sequence of the model actinomycete Streptomyces coelicolor A3(2). Nature 417, 141-147 (2002).

3 Ikeda, H. et al. Complete genome sequence and comparative analysis of the industrial microorganism Streptomyces avermitilis. Nat. Biotechnol. 21 526-531 (2003).

4 Ohnishi, Y. et al. Genome sequence of the streptomycin-producing microorganism Streptomyces griseus IFO 13350. J. Bacteriol. 190, 4050-4060 (2008).

5 Onaka, H., Mori, Y., Igarashi, Y. \& Furumai, T. Mycolic acid-containing bacteria induce natural-product biosynthesis in Streptomyces species. Appl. Environ. Microbiol. 77, 400-406 (2011).

6 Igarashi, Y. et al. Alchivemycin A, a bioactive polycyclic polyketide with an unprecedented skeleton from Streptomyces sp. Org. Lett. 12, 3402-3405 (2010).

7 Yassin, A. F. et al. Tsukamurella pulmonis sp. nov. Int. J. Syst. Bacteriol. 46, 429-436 (1996).

8 Kojiri, K. et al. A new antitumor substance, BE-13793C, produced by a streptomycete. J. Antibiot. 44, 723-728 (1991).

9 Reddy, G. M., Chen, S.-Y. \& Uang, B.-J. A Facile synthesis of indolo[2,3-a]pyrrolo[3,4c]carbazoles via oxidative photocyclization of bisindolylmaleimides. Synthesis 4, 0497-0500 (2003).

10 Mosmann, T. Rapid colorimetric assay for cellular growth and survival: application to proliferation and cytotoxicity assays. J. Immunol. Methods 65, 55-63 (1983).

Supplementary Information accompanies the paper on The Journal of Antibiotics website (http://www.nature.com/ja) 